\title{
FIELD EVALUATION AND GENETIC DIVERSITY FOR HEAT TOLERANCE USING STRESS INDICES AND SSR MARKERS IN RICE
}

\author{
Tahany M. Mazal \\ Rice Research Department, Field Crops Research Institute, Agricultural Research Center, \\ Giza, Egypt
}

Received: May 9, 2021

Accepted: May 22, 2021

\begin{abstract}
High temperature is a major environmental stress factor limiting rice productivity. The present investigation was carried out to evaluate and identify heat tolerant rice genotypes on the basis of heat indices and SSR markers. Fifteen rice genotypes were designed in Randomized Complete Block Design (RBCD) with three replications under normal and heat stress conditions at two environmentally different sites (Sakha and New Vally) during 2018 and 2019 rice season. Parameters of heat indices were calculated based on grain yield under both conditions. The results indicated that the heat tolerant index ( $\mathrm{HTI}$ ) and mean productivity (MP) index had the highest correlation with yield under two the conditions, Giza178, Giza179, Giza182, Egyptian Yasmin, Egyptian Hybrid1 and N22 were the best genotypes based on indices values, representing high temperature tolerance of these genotypes. Results of variance analysis of yield and other traits in both conditions showed that there was a significant difference among genotypes and their traits. Egyptian hybrid 1 produced the highest mean values of grain yield/plant under normal and heat stress conditions (50.26 and $37.00 \mathrm{~g} / \mathrm{plant}$ ), meanwhile Sakha102 had the highest reduction (70.36\%) and N22 had the lowest reduction (23.9\%). All genotypes clearly grouped into two major clusters in the dendrogram at $58 \%$ similarity based on Jaccard's similarity index. The first cluster represents the Indica and Indica/Japonica tolerant rice genotypes for high heat, while the second cluster represents the Japonica sensitive genotypes for high heat.
\end{abstract}

Key words: Heat tolerance, Genetic diversity, SSR markers, rice.

\section{INTRODUCTION}

Rice is one of the important stable cereal crops feeding more than $\mathbf{3 . 5}$ billion global population (IRRI, 2017). Increasing rice production as a national goal could be achieved through increasing the production per unit area, but environmental stresses are limiting this goal. Heat stress in particular is affecting agricultural crops more frequently and more severely (Janni et al., 2020 and Jagadish et al., 2010) reported that rice responses to high temperature differ according to the developmental stage, with the highest sensitivity recorded at the reproductive stage. Temperatures $>$ $35^{\circ} \mathrm{C}$ at anthesis and lasting for more than $(1 \mathrm{~h})$ can lead to high sterility in rice. each degree-Celsius increase in global mean temperature would, on average, reduce global yields of Wheat by $6.0 \%$, Rice by $3.2 \%$, Maize by $7.4 \%$, and Soybean by $3.1 \%$ (Liu et al., 2017). The genetics of heat tolerance is poorly understood, because it's complex and controlled by multiple genes (Wahid et al., 2007 and Xue et al., 2012; Driedonks et al., 2016). High temperature stress caused abnormal anther dehiscence and poor pollen germination which in turn increased spikelet sterility (Jagadish et al., 2010). Heat stress during flowering stage negatively impacts both percent seed set and total grain yield (Bui et al., 
2014). The critical physiological parameter "spikelet with exerted anthers but with no ovule enlargement" was considered as the most sensitive stage with exposure to heat stress at important reproductive stages (Shi et al., 2015). Heat stress reduce the rice production significantly especially during grainfilling period in most parts of the world where the temperature becomes high during anthesis to maturity (grain-filling) stage of plant growth (Dhanda and Munjal 2009). Direct selection under field conditions is generally difficult because uncontrollable environmental factors adversely affect the precision and repeatability of such traits. Assessment of heat tolerance at the molecular level is more meaningful than at phenotypic level as the later involves data on morphological traits which are environmental dependent. Available genetic diversity in rice offers opportunity for the breeders to develop genotypes with wider adaptability having resistance to biotic and abiotic stresses by selection of recombinants of desired genes. The simple sequence repeats (SSR) markers can help breeders to select genotypes carrying gene(s) of interest (Sadat et al., 2013), therefore, molecular maps based on these markers provide the breeders efficient strategies that may optimize time and resources and facilitate their manipulation in segregating plant breeding populations. These are powerful tools for many studies for genome characterization, detection of quantitative trait loci (QTL) for both abiotic and biotic stresses, evolutionary studies, and for marker assisted selection (MAS) (Chu et al., 2010 and Sadat et al., 2013). This study aimed to determination of genetic components for heat tolerance, determination of the best heat tolerant genotypes and identification of SSR markers linked to heat tolerance.

\section{MATERIALS AND METHODS}

\section{Rice materials}

Fifteen rice genotypes, including nine Japonicas, three Indica and three Indica/Japonica rice genotypes were selected for the current study. Seeds were obtained from genetic stock of Rice Research and Training Center (RRTC). The studied genotypes names, type and pedigree are presented in Table 1.

Table (1). list of Rice genotypes used in the experiment along with their type and pedigree.

\begin{tabular}{|l|l|c|c|}
\hline No & \multicolumn{1}{|c|}{ Genotypes } & Type & Parentage \\
\hline 1 & Sakha 101 & Japonica & Giza176/Milyang79 \\
\hline 2 & Sakha 102 & Japonica & GZ4098-7-1/Giza177 \\
\hline 3 & Sakha103 & Japonica & Giza 177/Suweon 349 \\
\hline 4 & Sakha104 & Japonica & GZ4096-8-1/GZ4100-9-1 \\
\hline 5 & Sakha105 & Japonica & GZ5581-46-3 / GZ4316-7-1-1 \\
\hline 6 & Sakha106 & Japonica & Giza177/Hexi30 \\
\hline 7 & Sakha107 & Japonica & Giza 177 /BLI \\
\hline 8 & Sakha108 & Japonica & Sakha 101/HR5824/Sakha 101 \\
\hline 9 & Giza 177 & Japonica & Giza171/Yomjo No.1//PiNo.4 \\
\hline 10 & Giza178 & Indicaljaponica & Giza175/Milyang49 \\
\hline 11 & Giza179 & Indica/Japonica & GZ6296 / GZ1368 \\
\hline 12 & Giza182 & Indica & Giza181/IR65844-29-1-3-1-2 \\
\hline 13 & EgyptianYasmin & Indica & IR262-43-8-11 / KDML 105 \\
\hline 14 & Egyptian hybrid 1 & Indicaßjaponica & IR69625A/Giza178 \\
\hline 15 & N22 & Indica & Unknown \\
\hline
\end{tabular}




\section{Field evaluation}

The field experiments were done at two locations, i.e., at Sakha Research Station, Rice Research and Training Center (RRTC), Kafr EL-Sheikh Governorate and at New Valley Research Station, El-Kharga, New Valley Governorate, Agriculture Research Center (ARC), Egypt, during the two successive seasons 2018 and 2019. Air temperature $\left({ }^{\circ} \mathrm{C}\right)$ and relative humidity (\%) were averaged for every month during 2018 and 2019 rice growing seasons, at the two locations as shown in Table (2). Fifteen rice genotypes (varieties and/or lines) representing a wide range of diverse genetic materials for several agronomic, physiological characters and heat tolerance levels were selected for this study. Seeds of the studied genotypes were sown in the nursery and after 30 days from sowing, seedlings of each genotype were individually transplanted in the permanent field in 5 rows $20 \mathrm{~cm}$ between rows and hills. The experiment was laid out in Randomized Complete Block Design (RCBD) with three replications according to Snedecor and Cochran (1967). All agronomic practice such as fertilization, irrigation, weeds and pests control were done recommended with rice crop during growing seasons of study. Data were collected on days to $50 \%$ heading (day), plant height (cm), number of panicles/plant, panicle length (cm), panicle weight (g), 1000-grain weight (g),sterility (\%) and grain yield (g/p), according to the standard evaluation system for rice (RRTC, 2018). Heat tolerance indices were calculated by the following formulas in Table 3.

Table (2): The maximum and minimum temperature $\left({ }^{\circ} \mathrm{C}\right)$ for months as well as relative humidity (\%) at Sakha Agricultural Research Station and New Valley Agricultural Research Station during rice seasons 2018 - 2019.

\begin{tabular}{|l|c|c|c|c|c|l|}
\hline \multirow{2}{*}{ Month } & \multicolumn{2}{|c|}{ KafrEL-Sheikh Governorate } & \multicolumn{3}{c|}{ New Vally Governorate } \\
\cline { 2 - 3 } & Air Temp.2018-2019 & & \multicolumn{2}{c|}{ Air Temp.2018-2019 } & \multirow{2}{*}{ RH\% } \\
\cline { 2 - 3 } \cline { 5 - 6 } May & Max & Min & RH\% & Max & Min & \\
\hline June & $32.6-31.9$ & $25.3-23.8$ & 59.7 & $40.5-42.3$ & $21-23$ & 23.5 \\
\hline July & $34.2-33.0$ & $25.4-25.3$ & 61.7 & $40.8-41.5$ & $26.3-25.8$ & 23 \\
\hline August & $33.9-33.5$ & $25.2-25.4$ & 66.8 & $43.2-41.5$ & $25.8-26.4$ & 27 \\
\hline September & $32.8-34.2$ & $23.5-25.2$ & 66.9 & $42.1-42.4$ & $27.2-26.7$ & 28.6 \\
\hline
\end{tabular}

Table (3). Heat tolerance indices

\begin{tabular}{|l|l|l|}
\hline Index & Formula & Reference \\
\hline Heat sensitive index (HSI) & {$[(1-(\mathrm{Ys} / \mathrm{Yn})] /$ SI } & Fischer and Maurer, 1978 \\
\hline Stress tolerance index (STI) & $(\mathrm{Yn} * \mathrm{Ys}) /(\mathrm{Yn})^{2}$ & Fernandez 1992 \\
\hline Mean productivity (MP) & $(\mathrm{Yn}+\mathrm{Ys}) / 2$ & $\begin{array}{l}\text { Hossain et al.,1990 ;Mardeh et al. } \\
2006\end{array}$ \\
\hline Tolerance (TOL): & Yn - Ys & Rosielle and Hamblin,1981 \\
\hline Yield stability index (YSI) & Yn / Ys & Bouslama and Schapaugh, 1984 \\
\hline Yield index (YI) & Ys/ Mean of Ys & Gavuzzi et al. 1997; Lin et al.,1986 \\
\hline
\end{tabular}

Which, Ys =mean yield under stress,

$\mathrm{Yn}=$ mean yield under normal condition and $\mathrm{SI}=$ the stress intensity. 


\section{Genomic DNA isolation}

Leaves were sampled from 15 days old seedling to extract genomic DNA for molecular screening of high temperature tolerance amongst the genotypes. Total genomic DNA was extracted after crushing in liquid nitrogen in microfuge tubes using CTAB method described by (Murray and Thompson 1988). The quantity and quality of DNA was assessed with $0.8 \%$ agarose gel electrophoresis using diluted uncut lambda phage DNA as size standard. The concentration of DNA was adjusted to approximately $15 \mathrm{ng} / \mu \mathrm{l}$ for PCR reaction.

\section{PCR amplification and electrophoresis}

Genetic diversity for 15 genotypes was screening using 16 SSR markers are linked to heat tolerance. Primers names, sequences, chromosome number and references are listed in Table 4. PCR amplification reactions was performed in $10 \mu$ reaction mixtures, containing $1 \mu$ l of template DNA, $2 \mu \mathrm{l}$ of each forward and reverse primers, $3 \mu \mathrm{lddH} O$ and $5 \mu \mathrm{l}$ of 2X GoTaq Green Master Mix (Promega, USA.). The reaction mixture was first denatured for $5 \mathrm{~min}$ at $95^{\circ} \mathrm{C}$ for, followed by 35 cycles of denaturation for $1 \mathrm{~min}$ at $94^{\circ} \mathrm{C}$ for, annealing at $T_{m}-2^{\circ} \mathrm{C}$ for 30 seconds and elongation at $72^{\circ} \mathrm{C}$ for $1 \mathrm{~min}$, and a final extension at $72^{\circ} \mathrm{C}$ for $10 \mathrm{~min}$. PCR amplification was loaded in $3 \%$ agarose gel containing Ethidium Bromide for electrophoresis in 1X TAE (pH 8.0). DNA ladder (50bp) was used for determination of size of amplicons. The gel was run at 60 volts $(2.5 \mathrm{~V} / \mathrm{cm})$ for $3 \mathrm{hrs}$ and photographed using Biometra gel documentation unit (BioDoc, Biometra, Germany)

Table (4). List of SSR markers sequences and chromosome number.

\begin{tabular}{|c|c|c|c|c|}
\hline \multirow{2}{*}{$\begin{array}{l}\text { Primer } \\
\text { name }\end{array}$} & \multirow{2}{*}{\begin{tabular}{|l|} 
Chromosome \\
number
\end{tabular}} & \multicolumn{2}{|l|}{ Sequence } & \multirow[t]{2}{*}{ reference } \\
\hline & & Forward & Reverse & \\
\hline RM3586 & 3 & GAAGAGAGAGCCAGAGCCAG & ACACGATCGAGCTAGAAGACG & \multirow{2}{*}{$\begin{array}{c}\text { Bui Chi } \\
\text { Buu et a } \\
\text { (2013) }\end{array}$} \\
\hline RM3735 & 4 & GCGACCGATCAGCTAGCTAG & ATAACTССTСССTTGСTGCC & \\
\hline RM6100 & 10 & TССТСTACCAGTACCGCACC & GCTGGATCACAGATCATTGC & $\begin{array}{c}\text { kumar et } \\
(2014)\end{array}$ \\
\hline RM160 & 9 & AGCTAGCAGCTATAGCTTAGCTGAGATCG & TCTCATCGCCATGCGAGGCCC & \multirow{4}{*}{$\begin{array}{c}\text { Buu et al } \\
2014\end{array}$} \\
\hline RM310 & 8 & CCAAAACATTTAAAATATCATG & GCTTGTTGGTCATTACCATTC & \\
\hline RM3471 & 4 & AGATCCCGACAGATGGTGAC & AACAGAGGGAGGGAGCAGAG & \\
\hline RM5687 & 4 & GATCGCTGGCGATTGATC & GACTTGTGGGGTGGTTTTTG & \\
\hline RM471 & 4 & ACGCACAAGCAGATGATGAG & GGGAGAAGACGAATGTTTGC & \multirow{2}{*}{$\begin{array}{c}\text { xiao et a } \\
2011\end{array}$} \\
\hline RM190 & 6 & СTTTGTCTATCTCAAGACAC & TTGCAGATGTTCTTCCTGATG & \\
\hline RM225 & 6 & TGCCCATATGGTCTGGATG & GAAAGTGGATCAGGAGGC & \\
\hline RM592 & 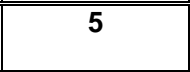 & TCTTTGGTATGAGGAACACC & AGAGATCCGGTTTGTTGTAA & $\begin{array}{c}\text { Cao et } \\
\text { al. (2015) }\end{array}$ \\
\hline RM405 & 5 & TCACACACTGACAGTCTGA & AATGTGGCACGTGAGGTAAG & $\begin{array}{l}\text { Zhanget } \\
\text { al. (2008) }\end{array}$ \\
\hline RM148 & 3 & CAACATTAGGGATGAGGCTGG & TCCTTAAAGGTGGTGCAATGCGAG & $\begin{array}{l}\text { Chen et } \\
\text { al. (2008) }\end{array}$ \\
\hline RM153 & 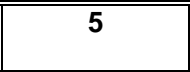 & GCCTCGAGCATCATCATCAG & ATCAACCTGCACTTGCCTGG & $\begin{array}{l}\text { Zhao et } \\
\text { al. (2016) }\end{array}$ \\
\hline RM430 & 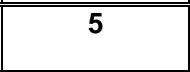 & AAACAACGACGTCCCTGATC & GTGCCTCCGTGGTTATGAAC & $\begin{array}{l}\text { Chenget } \\
\text { al. (2012) }\end{array}$ \\
\hline RM440 & $\overline{5}$ & CATGCAACAACGTCACCTTC & ATGGTTGGTAGGCACCAAAG & $\begin{array}{l}\text { Chenget } \\
\text { al. (2012) }\end{array}$ \\
\hline
\end{tabular}




\section{Data analysis}

Scoring of amplified bands was done as present (1) or absent (0) for each genotype and primer pair. To identify the informative SSR marker, polymorphism information content (PIC) value for each SSR marker was analyzed using the software package, NTSYS-pc version 2.11 (Rolf, 1988). The total number of amplified bands, number of polymorphic alleles number of amplified alleles and polymorphism ratio ( $P$ \%) and Polymorphism information content (PIC) were calculated to assess the diversity of alleles of marker locus (Anderson et al., 1993). Genetic similarity coefficients were used to construct a dendrogram using the Unweighted Pair Group Method with Arithmetic Average (UPGMA) sequential agglomerative hierarchal nested (SHAN) cluster.

\section{RESULTS AND DISCUSSION}

\section{Analysis of variance:}

The Analysis of variance under normal and heat stress conditions were revealed highly significant differences among rice genotypes for all studied traits Table 5 . These results showed a wide range of variability among rice genotypes and this gives an opportunity for rice breeders to improve these traits through selection and hybridization to improve the desired traits and enable to select genotypes under heat tolerant genotypes. Similar results were found by kumar and Saravanan 2012 and Gaballa et al., 2019.

Data in Tables 6 and 7 shows the mean performances of the $\mathbf{1 5}$ genotypes under normal and heat condition for the eight traits included days to heading , plant height, No. of panicles/plant, panicle length, panicle weight, 1000-grain weight, sterility $\%$ and grain yield/plant.
High temperature stress reduce plant duration via stimulate rice genotypes to early flowering, decrease plant height, and panicle length, reduce number of panicle/plant and produced the lowest panicle weight and 1000-grain weight. Moreover, the grain yield/plant was significantly reduced, whereas the minimum values $(13.0 \mathrm{~g} / \mathrm{p})$ under heat stress, in compared to $(50.3 \mathrm{~g} / \mathrm{p})$ under normal condition. The increment of temperature had significant negative effect on the grain productivity. On the other hand, high heat stress has increased sterility \%. The normal condition under Sakha Research Station had given the desirable mean values for all genotypes performance for pervious mentioned traits. These results are in agreement with Abdallah, 2015 and Gaballa et al., 2019. However the optimum temperature for the normal development of rice ranges from 27 to 32 ${ }^{\circ} \mathrm{C}$ (Yin et al., 1996), and high temperature affects almost all the growth stages of rice, i.e. from emergence to ripening and harvesting. The developmental stage at which the plant is exposed to heat stress determines the severity of the possible damage to the crop (Wahid et al., 2007). In addition, the most stages of development, which are considered to be sensitive to temperature in rice are flowering (anthesis and fertilization) and to a lesser extent the preceding booting stage (Satak and Yoshida 1978; Farrell et al., 2006). IRRI 1976 stated that exposure to $41{ }^{\circ} \mathrm{C}$ for $4 \mathrm{~h}$ at flowering caused irreversible damage and plants became completely sterile. Whereas this high temperature $\left(41^{\circ} \mathrm{C}\right)$ had no effect on spikelet fertility at 1 day before or after flowering (Yoshida et al., 1981). 
Table (5). Analysis of variance for studied traits under normal and heat stress.

\begin{tabular}{|c|c|c|c|c|c|c|c|c|c|}
\hline \multirow[t]{2}{*}{ S. O. V. } & \multirow[t]{2}{*}{$\mathbf{d f}$} & \multicolumn{2}{|c|}{$\begin{array}{c}\text { Days to } \\
\text { heading(day) }\end{array}$} & \multicolumn{2}{|c|}{ Plant height(cm) } & \multicolumn{2}{|c|}{ Panicles/plant } & \multicolumn{2}{|c|}{$\begin{array}{c}\text { Panicle } \\
\text { length }(\mathrm{cm})\end{array}$} \\
\hline & & $\mathbf{N}$ & $\mathbf{s}$ & $\mathbf{N}$ & $\mathbf{s}$ & $\mathbf{N}$ & $\mathbf{S}$ & $\mathbf{N}$ & $\mathbf{S}$ \\
\hline Replications & 2 & 0.69 & 1.69 & 0.27 & 4.84 & 6.02 & 1.40 & 7.14 & 0.43 \\
\hline Genotypes & 14 & $130.36^{* *}$ & 163.36 ** & $264.91 * *$ & $343.46 * *$ & $16.31^{* *}$ & $10.20 * *$ & $7.87^{\star *}$ & $8.44^{\star *}$ \\
\hline Error & 28 & 0.88 & 1.09 & 1.12 & 1.16 & 0.86 & 1.11 & 0.42 & 0.67 \\
\hline \multirow[t]{2}{*}{ S. O. v. } & \multirow[t]{2}{*}{ df } & \multicolumn{2}{|c|}{$\begin{array}{c}\text { Panicle } \\
\text { weight(g) }\end{array}$} & \multicolumn{2}{|c|}{$\begin{array}{l}\text { 1000-grain } \\
\text { weight }(g)\end{array}$} & \multicolumn{2}{|c|}{ Sterility\% } & \multicolumn{2}{|c|}{$\begin{array}{c}\text { Grain yield/plant } \\
\text { (g) }\end{array}$} \\
\hline & & $\mathbf{N}$ & s & $\mathbf{N}$ & $\mathbf{S}$ & $\mathbf{N}$ & $\mathbf{S}$ & $\mathbf{N}$ & $\mathbf{S}$ \\
\hline Replications & 2 & 0.02 & 0.00 & 0.05 & 0.27 & 2.94 & 11.89 & 1.81 & 2.55 \\
\hline Genotypes & 14 & $1.42^{* *}$ & $0.54^{\star *}$ & $21.70 * *$ & $48.77^{* *}$ & 51.46 ** & $414.87^{* *}$ & 104.00 ** & $211.58^{* *}$ \\
\hline Error & 28 & 0.01 & 0.01 & 0.37 & 1.05 & 0.75 & 8.96 & 0.64 & 0.81 \\
\hline
\end{tabular}

$\mathrm{N}$ : normal condition S: heat stress

Mean performance

Table 6. Mean performance of days to heading, plant height, panicles and panicle length for the studied genotypes under normal and heat stress.

\begin{tabular}{|l|c|c|c|c|c|c|c|c|}
\hline \multirow{2}{*}{ Genotypes } & \multicolumn{2}{|c|}{$\begin{array}{c}\text { Days to heading } \\
\text { (day) }\end{array}$} & \multicolumn{2}{c|}{$\begin{array}{c}\text { Plant height } \\
\text { (cm) }\end{array}$} & \multicolumn{2}{c|}{ Panicles/plant } & \multicolumn{2}{c|}{$\begin{array}{c}\text { Panicle length } \\
\text { (cm) }\end{array}$} \\
\cline { 2 - 9 } & $\mathrm{N}$ & $\mathrm{S}$ & $\mathrm{N}$ & $\mathrm{S}$ & $\mathrm{N}$ & $\mathrm{S}$ & $\mathrm{N}$ & $\mathrm{S}$ \\
\hline Sakha101 & 102.0 & 90.0 & 92.3 & 72.9 & 23.0 & 12.7 & 24.3 & 13.9 \\
\hline Sakha102 & 92.0 & 78.0 & 98.0 & 82.0 & 19.0 & 13.0 & 24.0 & 13.0 \\
\hline Sakha103 & 92.0 & 74.7 & 99.0 & 69.0 & 20.7 & 13.0 & 20.3 & 13.9 \\
\hline Sakha104 & 100.0 & 78.0 & 101.0 & 83.0 & 24.7 & 13.7 & 23.0 & 13.5 \\
\hline Sakha105 & 92.0 & 79.0 & 98.3 & 73.3 & 23.0 & 12.0 & 21.0 & 14.3 \\
\hline Sakha106 & 94.0 & 76.0 & 104.0 & 78.0 & 20.0 & 16.0 & 21.3 & 16.0 \\
\hline Sakha107 & 94.0 & 73.3 & 102.3 & 80.0 & 19.0 & 12.0 & 21.0 & 15.3 \\
\hline Sakha108 & 107.0 & 84.0 & 95.0 & 78.2 & 22.3 & 14.0 & 23.0 & 14.6 \\
\hline Giza177 & 90.3 & 77.0 & 99.0 & 70.0 & 18.0 & 14.0 & 22.0 & 13.3 \\
\hline Giza178 & 100.0 & 79.0 & 97.0 & 76.0 & 23.0 & 18.0 & 23.0 & 17.3 \\
\hline Giza179 & 91.7 & 71.0 & 93.7 & 80.3 & 23.0 & 16.7 & 21.0 & 18.0 \\
\hline Giza182 & 94.3 & 75.0 & 98.0 & 69.9 & 24.0 & 15.0 & 23.0 & 17.0 \\
\hline E. Yasmin & 112.0 & 96.0 & 109.7 & 83.0 & 25.0 & 14.0 & 25.0 & 17.0 \\
\hline E,Hybrid 1 & 106.0 & 76.0 & 107.7 & 83.0 & 25.0 & 15.0 & 26.0 & 16.0 \\
\hline N22 & 100.0 & 92.7 & 131.0 & 113.7 & 24.0 & 17.0 & 21.0 & 17.1 \\
\hline Grand mean & 98.2 & 79.9 & 101.7 & 79.4 & 22.4 & 14.4 & 22.5 & 15.3 \\
\hline Minimum value & 90.3 & 71.0 & 92.3 & 69.0 & 18.0 & 12.0 & 20.3 & 13.0 \\
\hline Maximum value & 112 & 96.0 & 131.0 & 113.7 & 25.0 & 18.0 & 26.0 & 18.0 \\
\hline LSD 0.05\% & 1.30 & 1.45 & 1.47 & 1.49 & 1.28 & 1.47 & 0.90 & 1.14 \\
\cline { 2 - 8 } 0.01 \% & 1.89 & 2.11 & 2.14 & 2.17 & 1.87 & 2.13 & 1.31 & 1.66 \\
\hline
\end{tabular}


Table 7. Mean performance of Panicle weight, 1000-grain weight, Sterility \% and Grain yield/plant for the studied genotypes under normal and heat stress.

\begin{tabular}{|l|c|c|c|c|c|c|c|c|}
\hline \multirow{2}{*}{ Genotypes } & \multicolumn{2}{|c|}{$\begin{array}{c}\text { Panicle weight } \\
\text { (g) }\end{array}$} & \multicolumn{2}{c|}{$\begin{array}{c}\text { 1000-grain } \\
\text { weight (g) }\end{array}$} & \multicolumn{2}{c|}{$\begin{array}{c}\text { Sterility } \\
(\%)\end{array}$} & \multicolumn{2}{c|}{$\begin{array}{c}\text { Grain } \\
\text { yield/plant (g) }\end{array}$} \\
\cline { 2 - 9 } & $\mathrm{N}$ & $\mathrm{S}$ & $\mathrm{N}$ & $\mathrm{S}$ & $\mathrm{N}$ & $\mathrm{S}$ & $\mathrm{N}$ & $\mathrm{S}$ \\
\hline Sakha101 & 4.1 & 1.0 & 28.7 & 14.0 & 9.6 & 40.0 & 47.8 & 17.9 \\
\hline Sakha102 & 3.6 & 1.2 & 28.5 & 11.0 & 9.8 & 43.3 & 43.9 & 13.0 \\
\hline Sakha103 & 3.0 & 1.5 & 23.5 & 13.0 & 8.1 & 41.0 & 35.6 & 17.0 \\
\hline Sakha104 & 3.9 & 1.7 & 24.8 & 15.0 & 6.3 & 38.0 & 42.7 & 15.0 \\
\hline Sakha105 & 3.7 & 1.2 & 27.3 & 13.0 & 8.0 & 37.0 & 46.4 & 19.0 \\
\hline Sakha106 & 3.9 & 1.7 & 28.6 & 16.0 & 8.2 & 49.1 & 46.2 & 20.0 \\
\hline Sakha107 & 3.1 & 1.4 & 27.0 & 13.0 & 7.8 & 45.0 & 37.2 & 20.0 \\
\hline Sakha108 & 4.3 & 1.2 & 28.4 & 14.0 & 9.4 & 47.0 & 48.2 & 16.0 \\
\hline Giza177 & 3.7 & 1.0 & 27.5 & 11.0 & 8.0 & 65.2 & 38.3 & 14.0 \\
\hline Giza178 & 4.1 & 2.4 & 24.1 & 20.0 & 7.7 & 24.0 & 46.5 & 34.2 \\
\hline Giza179 & 4.0 & 1.9 & 27.3 & 21.0 & 12.0 & 29.0 & 48.9 & 36.0 \\
\hline Giza182 & 3.7 & 1.9 & 24.0 & 21.0 & 13.4 & 32.0 & 47.8 & 33.0 \\
\hline E. Yasmine & 5.3 & 2.1 & 28.3 & 23.0 & 9.2 & 30.0 & 30.6 & 22.0 \\
\hline E,Hybrid 1 & 5.5 & 1.9 & 26.5 & 22.0 & 22.7 & 33.0 & 50.3 & 37.0 \\
\hline N22 & 3.3 & 1.9 & 20.7 & 17.0 & 5.1 & 18.0 & 38.1 & 29.0 \\
\hline Grand mean & 3.95 & 1.60 & 26.15 & 16.27 & 9.69 & 38.11 & 43.23 & 22.87 \\
\hline Minimum value & 3.0 & 1.0 & 28.7 & 11.0 & 5.1 & 18.0 & 30.6 & 13.0 \\
\hline Maximum value & 5.5 & 2.4 & 20.7 & 23.0 & 22.7 & 65.2 & 50.3 & 37.0 \\
\hline LSD 0.05\% & 0.13 & 0.12 & 0.84 & 1.42 & 1.20 & 4.16 & 1.11 & 1.25 \\
\cline { 2 - 8 } 0.01 \% & 0.19 & 0.17 & 1.23 & 2.07 & 1.74 & 6.05 & 1.62 & 1.82 \\
\hline
\end{tabular}

Mean performance and heat stress indices for grain yield.

Grain yield is the ultimate objective of any crop improvement program. Data in Table 8 showed that yield performance under normal (Yn) and heat stress conditions (Ys), decline \%, parameters of heat stress indices (HSI, HTI, MP, YI and YSI) to study heat tolerance and susceptibility in rice genotypes. All the indices were calculated on the basis of the mean of grain yield for the genotypes under normal and stress conditions. The mean of grain yield for the tested genotypes ranged from 50.26 to $30.57 \mathrm{~g} /$ plant under normal condition Table 9 and Figure 1. Egyptian Yasmin possessed minimum yield potential (30.57 g/plant), while Egyptian Hybrid1 had maximum grain yield with $50.26 \mathrm{~g} / \mathrm{plant}$, whereas grain yield ranged from $13.00 \mathrm{~g} / \mathrm{plant}$ for Sakha103 to $\mathbf{3 7 . 0 0}$ g/plant. Egyptian Hybrid1 had high yield under normal and heat stress. Mean comparison in Figure 1 illustrated that all genotypes gave high yielding under normal condition while under heat stress five genotypes gave the highest grain yield (Egyptian Hybrid1 followed by Giza179, Giza178, Giza182, and N22.Two rice genotypes gave moderate, Egyptian Yasmin and Sakha107and the other genotypes gave lowest grain yield. Depending on the specific stages of rice development, heat stress reduces number of tillersl panicle, decrease number of grains /panicle and lower grain weight, thus negatively affecting yield formation results observed by AbdelHafez et al., 2016 and Xu et al., 2020.Yield reduction $\%$ and the comparison of yield under normal and heat stress conditions 
and decline $\%$ are presented in Table 9 and Figures 2 \& 3. Sakha102 showed maximum yield reduction $70.36 \%$, while N22 recorded minimum yield reduction $23.90 \%$. Clearly, heat stress caused a significant reduction $(\mathbf{4 5 . 9 \% )}$ in grain yield. The highest reduction was found in Sakha102 (70.36\%) and the lowest reduction recorded for N22 (23.90\%). Generally all genotypes under heat stress produced low grain yield. Data in Table 2 show a rise of temperature during three month July, August and September ranged from 38.5 to $45{ }^{\circ} \mathrm{C}$ during initial reproductive and ripening stage explained and confirmed previous results in this study. The reduction in mean values of grain yield under heat stress condition studied by Thapa et al., 2020 and reported that increased temperature leads to rapid completion of rice life cycle resulting in poor expression of yield contributing traits and consequently lowers the grain yield. Nakagawa et al., 2003 reported that temperatures higher than the optimum induced floret sterility and thus decreased rice yield. When heat stress occurred during initial growth phases, i.e., booting and flowering, Aghamolki et al., 2014 noticed that greater yield reduction due to reduction in all the important yield components excluded effective tillers, i.e., fertile spikelets, 1000 grain weight and increase in sterile and aborted spikelets per panicle. In the initial reproductive stage usually infertile spikelets increase due to pollen infertility and anther dehiscence, accordingly the number of pollen scattered on stigma and the fertility and fertilization of pollens declined markedly.

Table (8): Mean performance of 15 rice genotypes for grain yield /plant, decline \% and five heat stress indices.

\begin{tabular}{|l|c|c|c|c|c|c|c|c|}
\hline $\begin{array}{l}\text { Heat } \\
\text { susceptible } \\
\text { genotype }\end{array}$ & $\begin{array}{c}\text { Grain } \\
\text { yield } \\
\text { (normal) }\end{array}$ & $\begin{array}{c}\text { Grain } \\
\text { yield } \\
\text { (stress) }\end{array}$ & $\begin{array}{c}\text { Decline } \\
\%\end{array}$ & HSI & HTI & MP & TOL & YSI \\
\hline Sakha 101 & 47.83 & 17.90 & 62.50 & 1.261 & 0.458 & 56.78 & 29.93 & 0.37 \\
\hline Sakha 102 & 43.87 & 13.00 & 70.36 & 1.418 & 0.305 & 50.37 & 30.87 & 0.30 \\
\hline Sakha103 & 35.57 & 17.00 & 52.09 & 1.052 & 0.324 & 44.07 & 18.57 & 0.48 \\
\hline Sakha104 & 42.73 & 15.00 & 64.89 & 1.308 & 0.343 & 50.23 & 27.73 & 0.35 \\
\hline Sakha105 & 46.44 & 22.00 & 52.62 & 1.061 & 0.547 & 57.44 & 24.44 & 0.47 \\
\hline Sakha106 & 46.23 & 21.00 & 54.57 & 1.100 & 0.519 & 56.73 & 25.23 & 0.45 \\
\hline Sakha107 & 37.15 & 20.00 & 45.78 & 0.993 & 0.397 & 48.15 & 17.15 & 0.54 \\
\hline Sakha108 & 48.24 & 16.00 & 66.80 & 1.347 & 0.413 & 56.24 & 32.24 & 0.33 \\
\hline Sakha177 & 38.25 & 14.00 & 63.39 & 1.278 & 0.287 & 45.25 & 24.25 & 0.37 \\
\hline $\begin{array}{l}\text { Heat } \\
\text { tolerant } \\
\text { genotypes }\end{array}$ & $\begin{array}{c}\text { Grain } \\
\text { yield }\end{array}$ & $\begin{array}{c}\text { Grain } \\
\text { yield }\end{array}$ & $\begin{array}{c}\text { Decline } \\
\text { (stress) }\end{array}$ & HSI & HTI & MP & TOL & YSI \\
\hline Giza178 & 46.53 & 34.16 & 26.50 & 0.576 & 0.850 & 63.61 & 12.38 & 0.73 \\
\hline Giza179 & 48.85 & 36.00 & 26.30 & 0.570 & 0.941 & 66.85 & 12.85 & 0.74 \\
\hline Giza182 & 47.79 & 33.00 & 30.90 & 0.670 & 0.844 & 64.29 & 14.79 & 0.69 \\
\hline $\begin{array}{l}\text { Egyptian } \\
\text { Yasmine }\end{array}$ & 30.57 & 22.00 & 28.03 & 0.607 & 0.360 & 41.57 & 8.57 & 0.72 \\
\hline E. hybrid 1 & 50.26 & 37.00 & 26.30 & 0.571 & 0.995 & 68.76 & 13.26 & 0.74 \\
\hline N22 & 38.14 & 29.00 & 23.90 & 0.519 & 0.592 & 52.64 & 9.14 & 0.76 \\
\hline
\end{tabular}

$\mathrm{HSI}=$ Heat Sensitive Index; HTI = Heat Tolerance Index; MP = Mean Productivity; TOL $=$ Tolerance and YSI $=$ Yield Stability Index . 
Field evaluation and genetic diversity for Heat Tolerance using stress indices .....

Table (9). Correlation between yield with heat stress indices for eight agro-morphological traits in 15 rice genotypes under normal and heat stress condition.

\begin{tabular}{|c|c|c|c|c|c|c|c|c|}
\hline Traits & Yn & Ys & HTI & TOL & YSI & MP & YI & HIS \\
\hline Yn & 1.00 & & & & & & & \\
\hline YS & .379 & 1.00 & & & & & & \\
\hline HTI & $.615^{*}$ & $.960^{* *}$ & 1.00 & & & & & \\
\hline TOL & .329 & $-.749^{* *}$ & $-.540^{*}$ & 1.00 & & & & \\
\hline YSI & -.065 & $.894^{* *}$ & $.735^{* *}$ & $-.959^{* *}$ & 1.00 & & & \\
\hline MP & $.887^{* *}$ & $.763^{* *}$ & $.908^{* *}$ & -.144 & .400 & 1.00 & & \\
\hline YI & .377 & $1.000^{* *}$ & $.959^{* *}$ & $-.751^{* *}$ & $.895^{* *}$ & $.762^{* *}$ & 1.00 & \\
\hline HIS & .095 & $-.862^{* *}$ & $-.699^{* *}$ & $.948^{* *}$ & $-.974^{* *}$ & -.363 & $-.863^{* *}$ & 1.00 \\
\hline
\end{tabular}

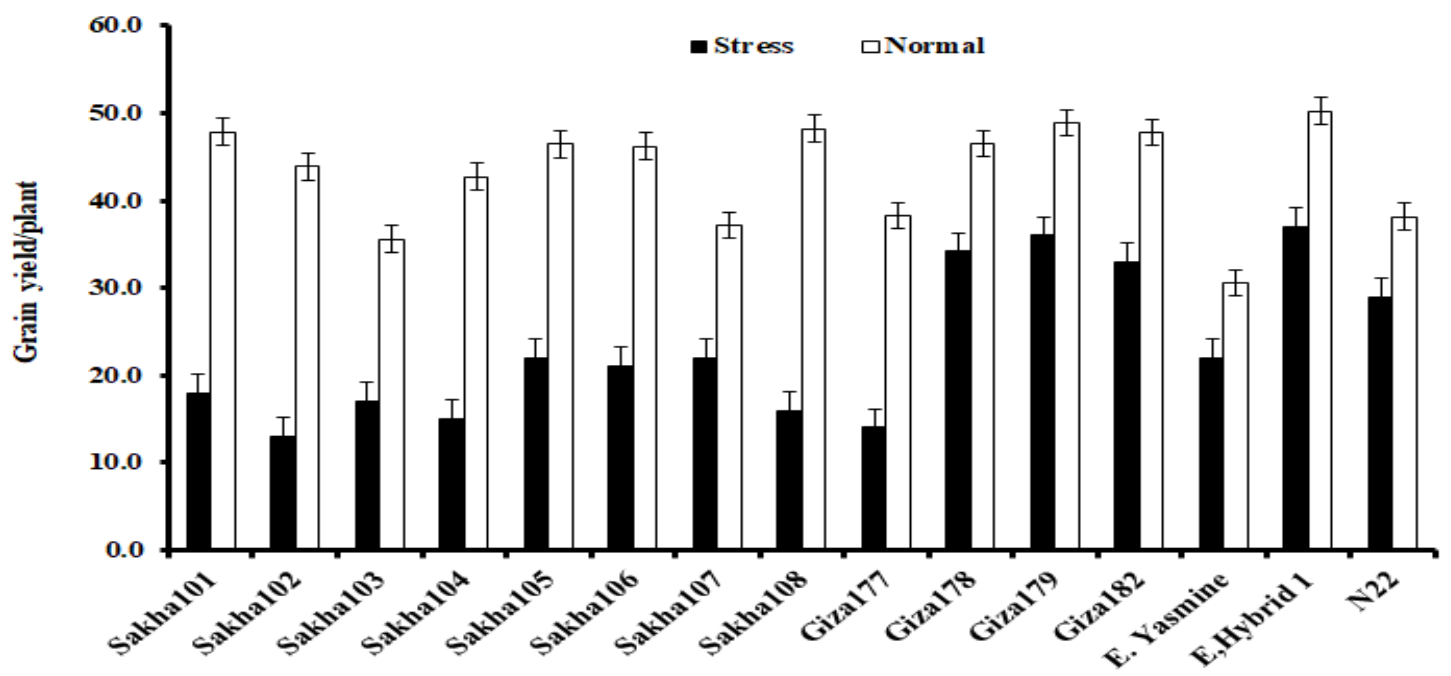

Figure (1): Mean performance for grain yield under normal and heat stress condition.

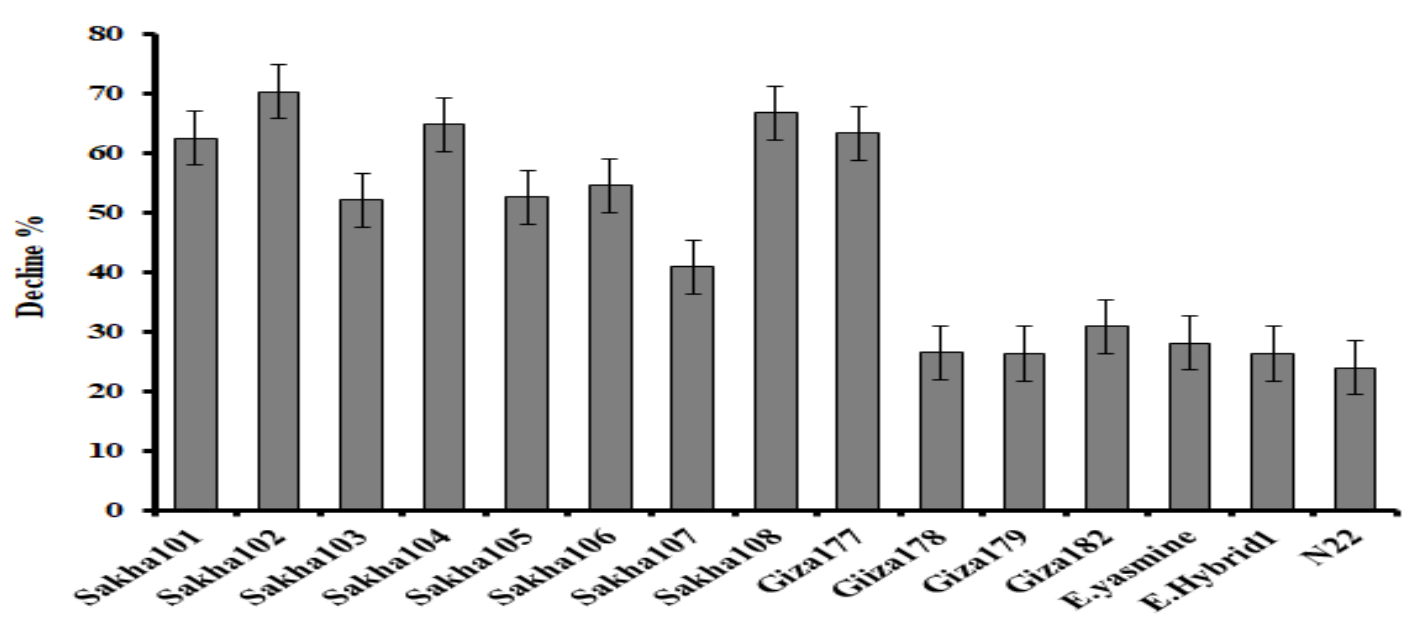

Figure (2): Decline \% for grain yield under heat stress condition. 


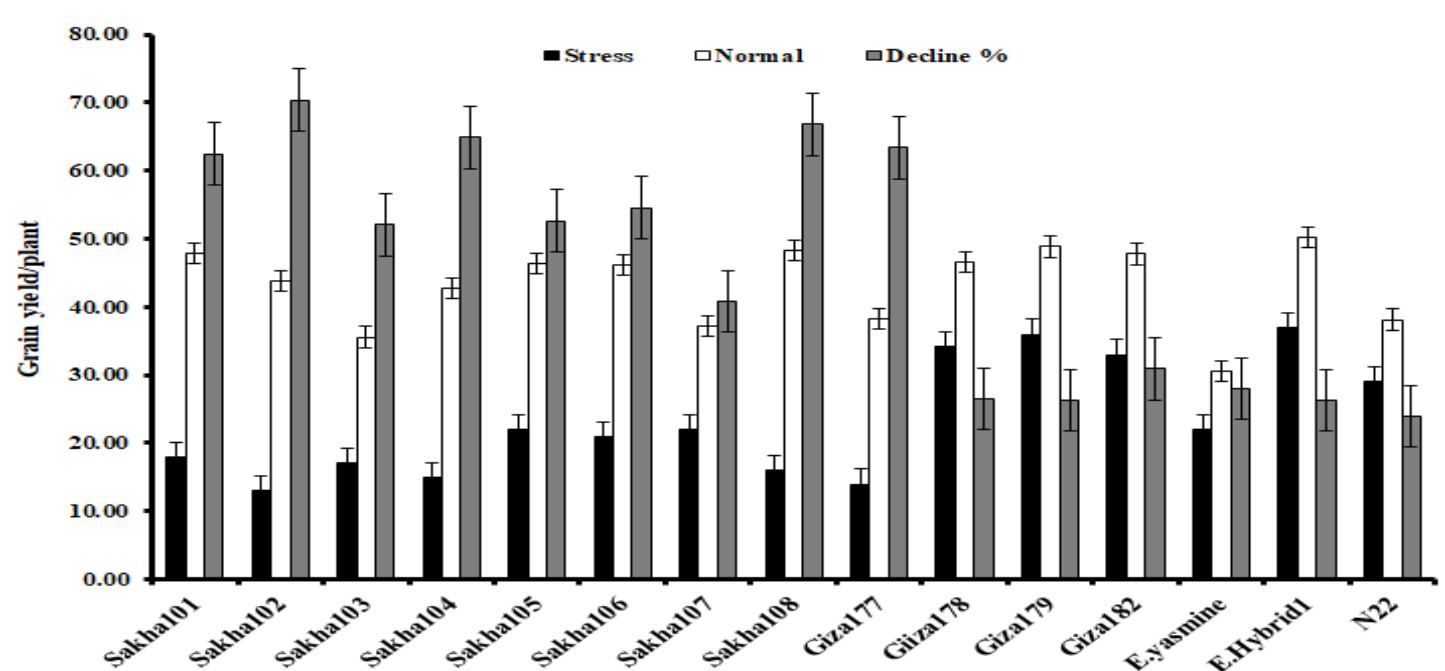

Figure (3): Comparison of yield under normal and heat stress condition and decline \%

\section{Heat Stress Indices}

To study heat tolerance and susceptibility in rice genotypes, we used five stress indices i.e., heat susceptible index (HIS), heat response index, stress tolerance, yield stability index and yield index. All the indices were calculated on the basis of the mean of grain yield of the genotypes under normal and stress conditions.

Heat susceptible index (HIS) data in Figure 4. The genotypes with low HSI 1 value are heat stress tolerance and the genotypes with high positive HIS values are susceptible for higher temperature (Reynolds et al., 1994 and fisher and maurer, 1978). The results showed that the genotypes Giza178, Giza179, Giza182, Egyptian Yasmin, Egyptian Hybrid1 and N22 had low values of HSI for yield trait. While, rice genotypes Sakha101, Sakha102, Sakha103, Saha104, Sakha105, Sakha106, Sakha108 and Giza177 gave high HSI values. Heat susceptible index (HIS) for the important index can be utilized for selection for tolerant genotypes. Heat response index (HRI) also calculated to confirm the above results. Maximum HRI value is the better indicator of the superior performance of genotype under heat stress environment (Fernandez 1992,
Mardeh et al., 2006). The rice genotypes Egyptian hybrid1 followed by Giza 179, Giza178, Giza182 and N22 with high HRI values indicating the tolerance heat stress while, genotype Sakha101, Sakha102, Sakha 103, Saha104, Sakha105, Sakha107, Sakha106, Sakha108, Egyptian Yasmin and Giza 177 showing susceptibility to heat Figure 5. Concerning Stress Tolerance (TOL), the genotypes with low TOL values are more stable in two different Conditions and suitable for the screening of breeding materials for heat tolerance). variability were found amongst the genotypes for tolerance (TOL) and rice genotypes Egyptian Yasmin, N22, Giza178, Giza 179, Giza 182 and Egyptian Hybrid 1 exhibited the lower TOL values and the genotypes intermediate Sakha107and the other genotypes were higher TOL values indicating non sensitive for the heat conditions. Figure 6. Similar results were recorded by several workers for selections based on these indices Ouk et al., 2006 and Mardeh et al., 2006. Mean Productivity Index (MPI), the genotypes with high values of MPI is more desirable index. Data in Figure 7 illustrated that Egyptian Hybrid 1, Giza179, Giza178 and Giza182 had desirable high MPI values and high tolerant to high temperature. 
For Yield Stability Index (YSI), maximum values are the better indication of the superior performance of genotypes under heat stress environment. Differences were found amongst the genotypes for $\mathrm{YSI}$ and as in case of HSI the genotype N22 had the highest YSI followed by Egyptian Hybrid1, Giza179, Giza178, Egyptian Yasmin and Giza.182 exhibited stability to stress while, the rest of genotypes had lower values exhibited instability under stress except Sakha107 genotype which was intermediate in nature Figure 8. Similar studies on these indices were carried out by many authors (khan et al., 2016 and himanshu et al., 2017). In case of Yield Index (YI); the rice genotype with high values of Yield index (YI) is suitable for heat condition. The genotype had $>1$ value considered tolerant while, the genotypes having $<1$ value denoted as sensitive one. The rice genotypes Egyptian Hybrid1, Giza179, Giza178, Giza182 and N22 showing higher values as in case of STI and MPI. Similarly lower values of $\mathrm{YI}$ were noted in the genotypes Sakha101, Sakha102, Sakha103, Sakha104, Sakha108 and
Giza177 exhibited sensitive to high heat and Egyptian Yasmin. Sakha107, Sakha106, Sakha105 were intermediate (Figure 9). It is clear from heat tolerance indices that indica and indica/japonica genotypes are more tolerant to high temperature than japonica genotypes, these results confirmed by Barakat et al., 2011and Shah et al., 2011. Among the examined indices HTI (0.615) and (0.960) and MP (0.887) and (0763) have positive and high significant correlation with grain yield/plant under normal and stress conditions, respectively Table 9 illustrated suitability of these indexes for rice selection. Positive and high significant correlation $\mathrm{YI}$ index with yield under heat condition but this index has low correlation with yield under normal condition. While, under stress condition data revealed that highly significant and positive correlation with HTI (0.959), YSI (0.895) and MP (0.762) and high significant negative correlation between HSI and HTI (-0.699). Many similar studies dissussed by Khan et al., 2016 Garg et al., 2017; Thapa et al., 2020 and Saha et al., 2020.

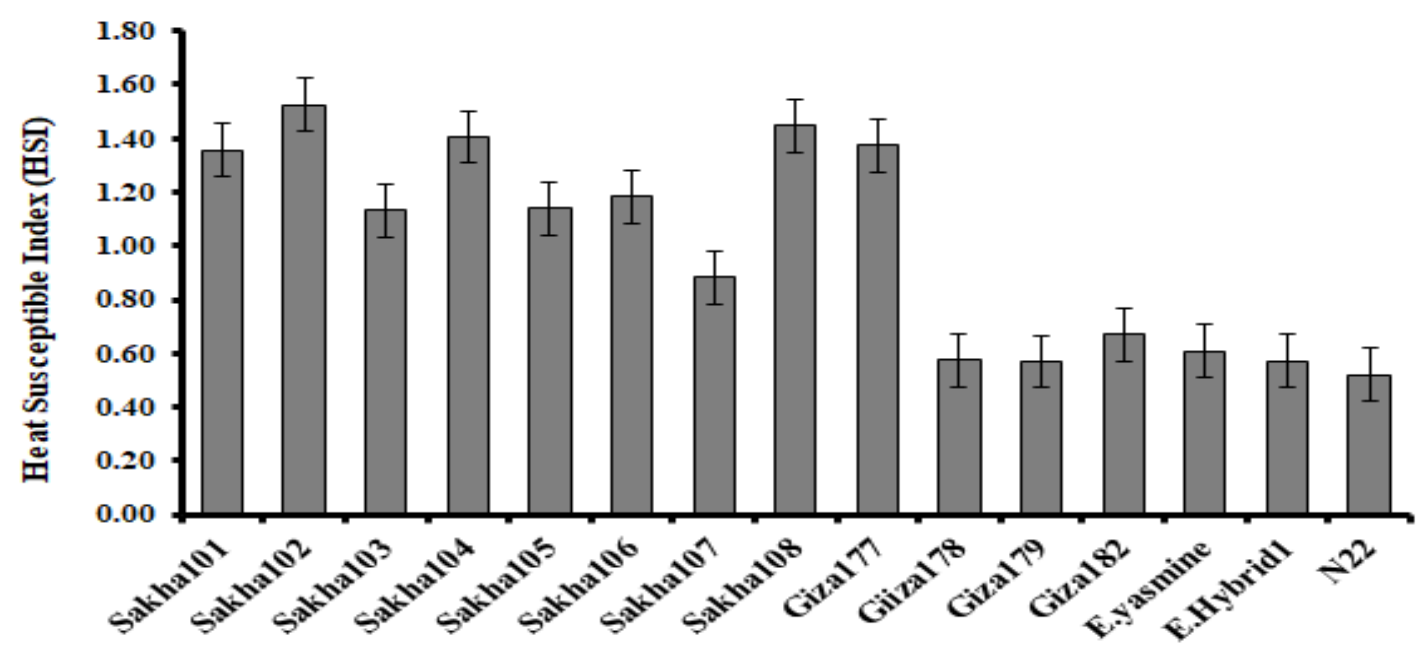

Figure (4). Heat Susceptible Index (HSI) on the basis of grain yield of the studied genotypes under normal and heat stress conditions. 


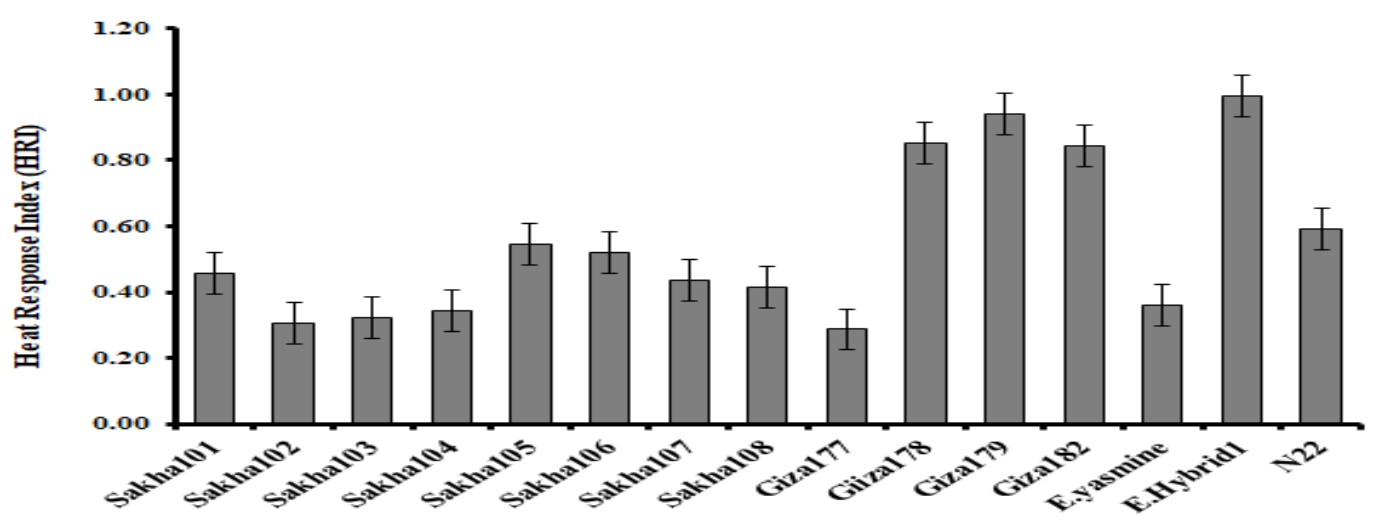

Figure (5). Heat response index (HRI) on the basis of grain yield of the studied genotypes under normal and heat stress condition.

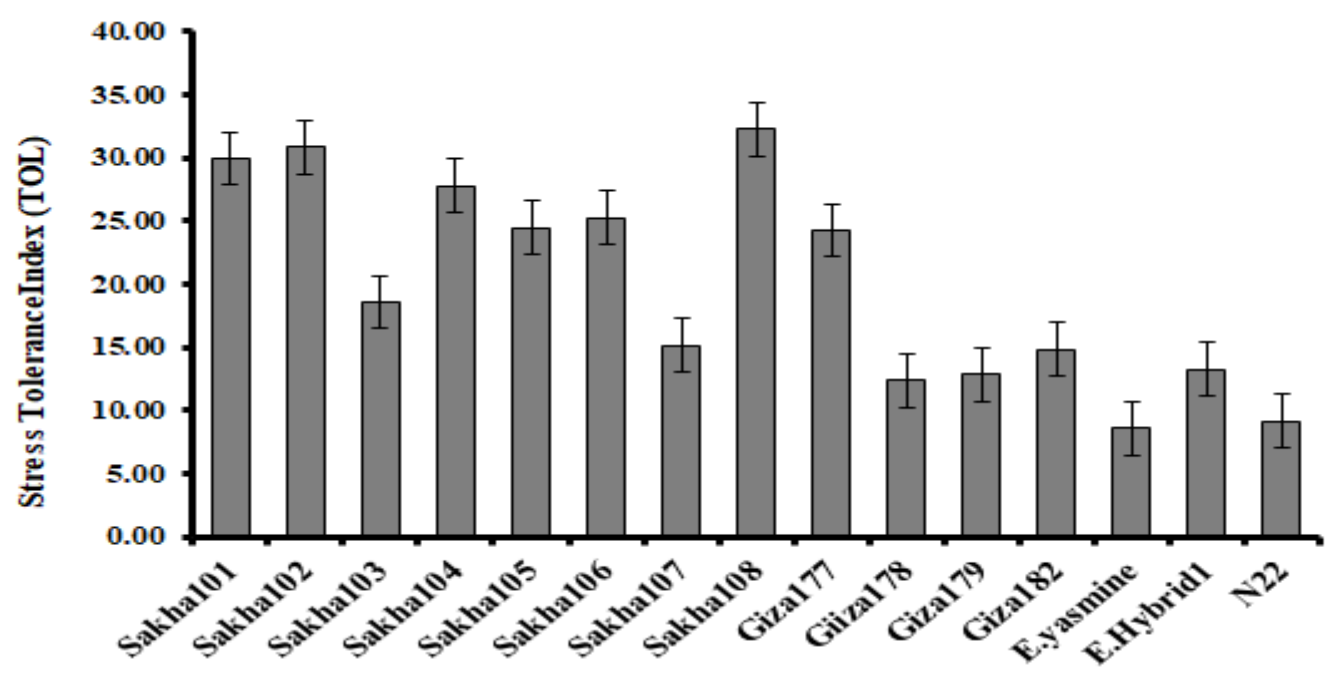

Figure (6): Stress Tolerance index (TOL) on the basis of grain yield of the studied genotypes under normal and heat stress condition.

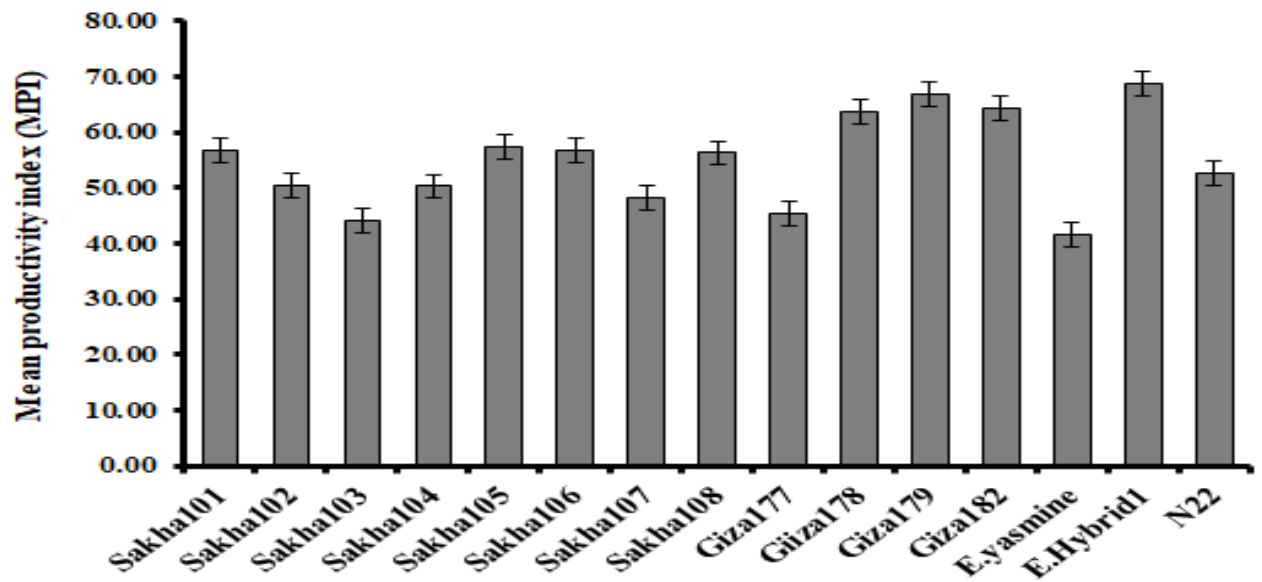

Figure (7): Mean productivity index (MPI) on the basis of grain yield of the studied genotypes under normal and heat stress condition. 


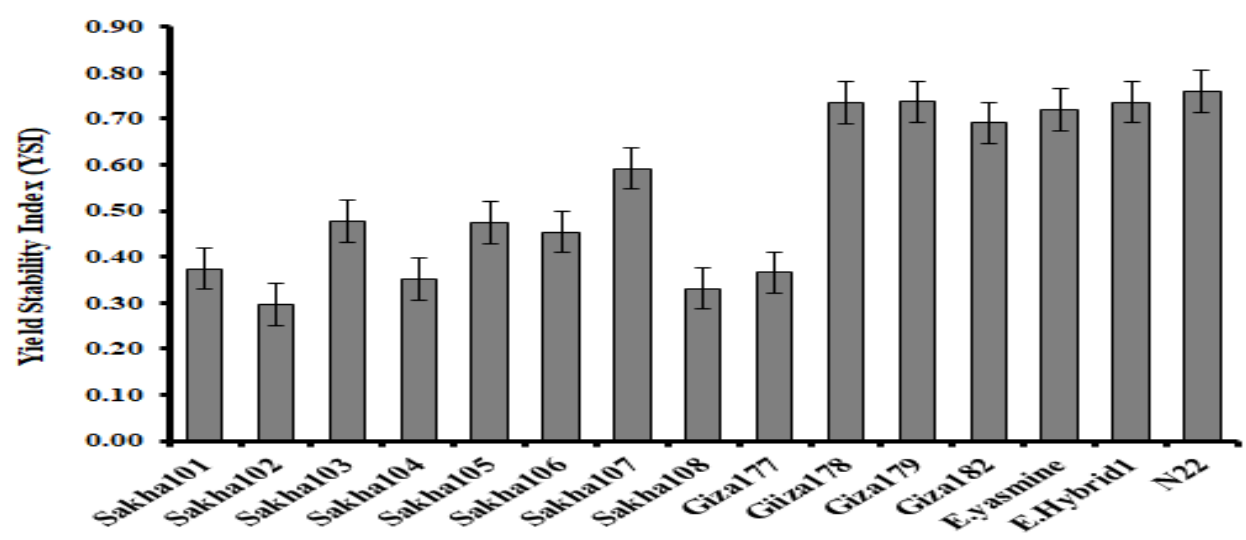

Figure (8): Yield Stability Index (YSI) on the basis of grain yield of the studied genotypes under normal and heat stress condition.

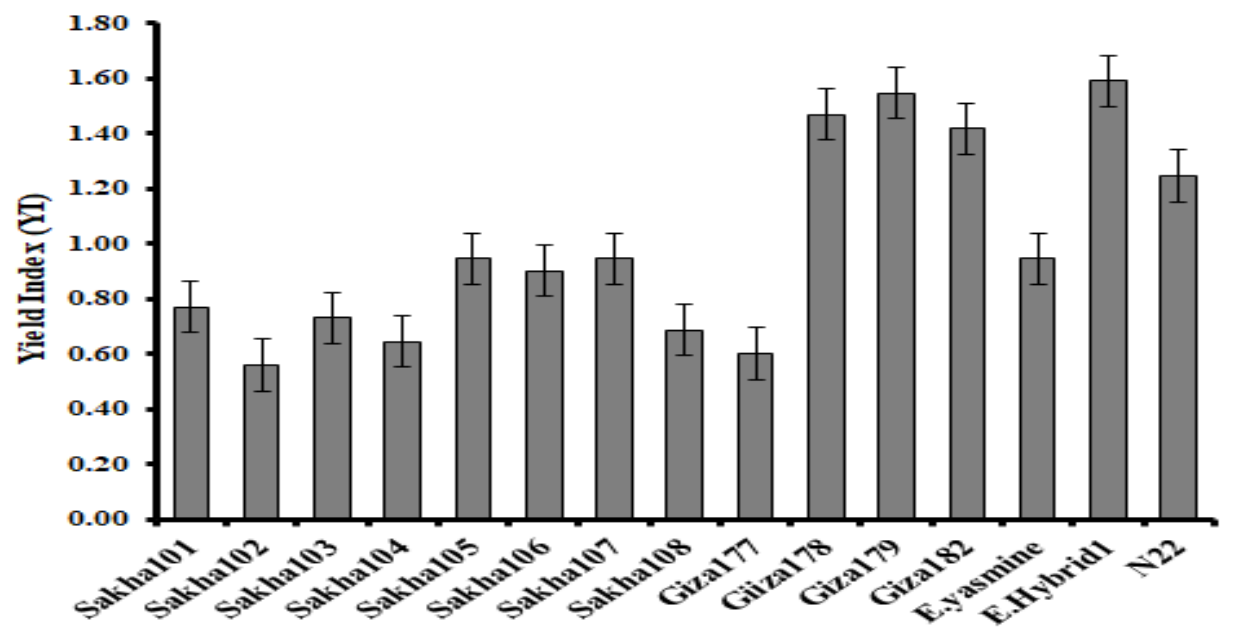

Figure (9): Yield Index (YI) on the basis of grain yield of the studied genotypes under normal and heat stress condition.

\section{Molecular analysis}

The results obtained in Table 10 based on the analysis of the 15 rice genotypes using polymorphic SSR loci to detect genetic variability under the molecular level. Among the sixteen SSR markers used for genotyping, four markers (RM3735, RM190, RM405 and RM471) were monomorphic, while 12 SSR markers generated polymorphic alleles among the studied genotypes and showed different levels of polymorphism. Based on the banding sizes and patterns, a UPGMA dendrogram was generated to elucidate the genetic relationships between the tested genotypes. A total of 241 amplified bands with an average of 14.18 amplified bands/primer. The number of alleles varied from 1 to 2 alleles $I$ locus, and 29 amplified alleles were found to be polymorphic which were amplified by 12 SSRs with an average 1.71.the polymorphic alleles play important roles for variety differentiation, diversity characterization and conservation potential parents (Pradhan,2016; Singh et al., 2016 and Ravindr et al., 2019.Polymorphism information content (PIC) values reflection of allele diversity and frequency among genotypes also varied 
from locus to another and provide an estimate of the discriminating power of the marker (Nagy et al., 2012). PIC value among the polymorphic markers varied from 0.00 for RM3735, RM471, RM190, RM592 and RM471 to 60 for RM225 with an average of 0.28 . The detected polymorphism reflects the amount of diversity among the tested genotypes and thus the possibility of genetic improvement using such a set of genotypes in breeding programs since genetic diversity is the prerequisite for successful such programs. Genetic similarity coefficient values for the studied genotypes are presented in Table 11. The coefficient of similarities based on data among the studied genotypes ranged from 0.22 to 1.0 with an average similarity index of 0.61 indicating wide genetic diversity present in studied genotypes. The lowest genetic similarity was observed between the pure Indica variety $\mathrm{N} 22$ and the pure Japonica variety Sakha105 (0.22), while the highest similarity was observed between both Japonica varieties Sakha102 and Sakha103 and Sakha105 also within Sakha 105 with Sakha103 also Giza178 with Egyptian hybrid1. Among Japonica genotypes, genetic similarity coefficients ranged from 0.50 and 1.0 with an average of 0.75 . The lowest similarity coefficient was observed between Sakha102, Sakha103, Sakha105 and the high yielding rice variety Sakha101. The genetic similarity among tested rice genotypes are presented in a dendrogram based on Jaccard's similarity index and UPGMA method Figure 10 provided a clear resolution of relationships among studied variety. At $36 \%$ similarity, the UPGMA cluster diagram clearly showed two major groups with additional sub-cluster with in each group. This dendogram showed that the cultivars derived from genetically similar type clustered together. Group A involved the high heat tolerant Indica and Indica/Japonica rice genotypes, while the group B involved the high sensitive Japonica rice genotypes (heat susceptible). The main group $A$ was further divided in two sub clusters $A_{1}$ and $A_{2}$ at $54 \%$ similarity, cultivar in this group is interest to rice breeders because some of them are used as a donors for breeding heat tolerance. Similarly, the main group (B) was further separated into two sub clusters, $B_{1}$ and $B_{2}$ at about $57 \%$ similarity. The sub clusters $A_{1}$ included the Indica rice variety Giza182 and the wide spread Indica/Japonica rice variety Giza178 and E. hybrid1,but Giza179 didn't group any sub cluster, while the sub cluster $A_{2}$ included the both Indica rice genotypes Egyptian Yasmine and N22.On the other hand, the sub cluster $B_{1}$ included both rice genotypes Sakha105 and Sakha104. The Japonica genotypes Sakha102, Sakha3 and Sakha105 were found in sub cluster $B_{2}$. while the genotypes Sakha 107, Giza177, Sakha108 and Saka106 didn't group any sub cluster. Finally, clustering genotypes in the constructed dendogram was largely dependent on their genetic background. The ability of cluster analysis to divide rice genotypes according to their genetic background and origin were summarized in different studies. El-malky, 2007; Mazal, 2014 and Ramadan et al., 2017 and found that all japonica Egyptian rice genotypes were grouped in one cluster while all Indica Egyptian rice genotypes were grouped another cluster. Representative banding pattern for 15 rice genotypes are shown in Fig 11. 
Field evaluation and genetic diversity for Heat Tolerance using stress indices .....

Table (10): Summary of Molecular analysis for tested genotypes using SSR markers.

\begin{tabular}{|l|c|c|c|c|c|}
\hline $\begin{array}{c}\text { SSR } \\
\text { marker }\end{array}$ & $\begin{array}{c}\text { \# of } \\
\text { amplified } \\
\text { bands }\end{array}$ & $\begin{array}{c}\text { \# of } \\
\text { amplified } \\
\text { alleles }\end{array}$ & $\begin{array}{c}\text { \# of } \\
\text { polymorphic } \\
\text { alleles }\end{array}$ & $\begin{array}{c}\text { Polymorphism } \\
\%\end{array}$ & $\begin{array}{c}\text { PIC } \\
\text { value }\end{array}$ \\
\hline RM148 & 15 & 2 & 2 & 100 & 0.48 \\
\hline RM5687 & 15 & 2 & 2 & 100 & 0.44 \\
\hline RM430 & 15 & 2 & 2 & 100 & 0.48 \\
\hline RM440 & 14 & 2 & 2 & 100 & 0.49 \\
\hline RM3586 & 13 & 2 & 2 & 100 & 0.23 \\
\hline RM3735 & 13 & 1 & 0 & 0 & 0 \\
\hline RM6100 & 14 & 2 & 2 & 100 & 0.24 \\
\hline RM160 & 13 & 2 & 2 & 100 & 0.35 \\
\hline RM310 & 15 & 2 & 2 & 100 & 0.23 \\
\hline RM3471 & 15 & 2 & 2 & 100 & 0.44 \\
\hline RM471 & 15 & 1 & 0 & 0 & 0 \\
\hline RM190 & 15 & 1 & 0 & 0 & 0 \\
\hline RM225 & 11 & 2 & 2 & 100 & 0.60 \\
\hline RM592 & 15 & 2 & 2 & 100 & 0.48 \\
\hline RM405 & 15 & 1 & 0 & 0 & 0 \\
\hline RM153 & 13 & 2 & 2 & 100 & 0.35 \\
\hline RM471 & 15 & 1 & 0 & 0 & 0 \\
\hline Total & 241 & 29 & 24 & & \\
\hline Average & 14.18 & 1.71 & 1.41 & 70.59 & 0.28 \\
\hline
\end{tabular}

Table (11): Similarity matrix among tested rice genotypes

\begin{tabular}{|l|l|l|l|l|l|l|l|l|l|l|l|l|l|l|l|}
\hline & Sk101 & Sk102 & Sk103 & Sk104 & Sk105 & Sk106 & Sk107 & Sk108 & G177 & G178 & G179 & G182 & Eyasmin & H1 & N22 \\
\hline Sk101 & 1.00 & & & & & & & & & & & & & & \\
\hline Sk102 & 0.50 & 1.00 & & & & & & & & & & & & & \\
\hline Sk103 & 0.50 & 1.00 & 1.00 & & & & & & & & & & & & \\
\hline Sk104 & 0.78 & 0.57 & 0.57 & 1.00 & & & & & & & & & & & \\
\hline Sk105 & 0.50 & 1.00 & 1.00 & 0.57 & 1.00 & & & & & & & & & & \\
\hline Sk106 & 0.60 & 0.65 & 0.65 & 0.68 & 0.65 & 1.00 & & & & & & & & & \\
\hline Sk107 & 0.52 & 0.94 & 0.94 & 0.60 & 0.94 & 0.68 & 1.00 & & & & & & & & \\
\hline Sk108 & 0.60 & 0.74 & 0.74 & 0.68 & 0.74 & 0.60 & 0.78 & 1.00 & & & & & & & \\
\hline G177 & 0.52 & 0.83 & 0.83 & 0.60 & 0.83 & 0.68 & 0.88 & 0.78 & 1.00 & & & & & & \\
\hline G178 & 0.33 & 0.43 & 0.43 & 0.39 & 0.43 & 0.28 & 0.45 & 0.45 & 0.39 & 1.00 & & & & & \\
\hline G179 & 0.32 & 0.48 & 0.48 & 0.43 & 0.48 & 0.32 & 0.50 & 0.57 & 0.43 & 0.65 & 1.00 & & & & \\
\hline G182 & 0.30 & 0.35 & 0.35 & 0.30 & 0.35 & 0.30 & 0.36 & 0.36 & 0.30 & 0.76 & 0.55 & 1.00 & & & \\
\hline Eyasmin & 0.45 & 0.27 & 0.27 & 0.45 & 0.27 & 0.33 & 0.28 & 0.39 & 0.28 & 0.52 & 0.57 & 0.50 & 1.00 & & \\
\hline H1 & 0.33 & 0.43 & 0.43 & 0.39 & 0.43 & 0.28 & 0.45 & 0.45 & 0.39 & 1.00 & 0.65 & 0.76 & 0.52 & 1.00 & \\
\hline N22 & 0.33 & 0.22 & 0.22 & 0.39 & 0.22 & 0.23 & 0.23 & 0.28 & 0.23 & 0.60 & 0.57 & 0.43 & 0.60 & 0.60 & 1.00 \\
\hline
\end{tabular}




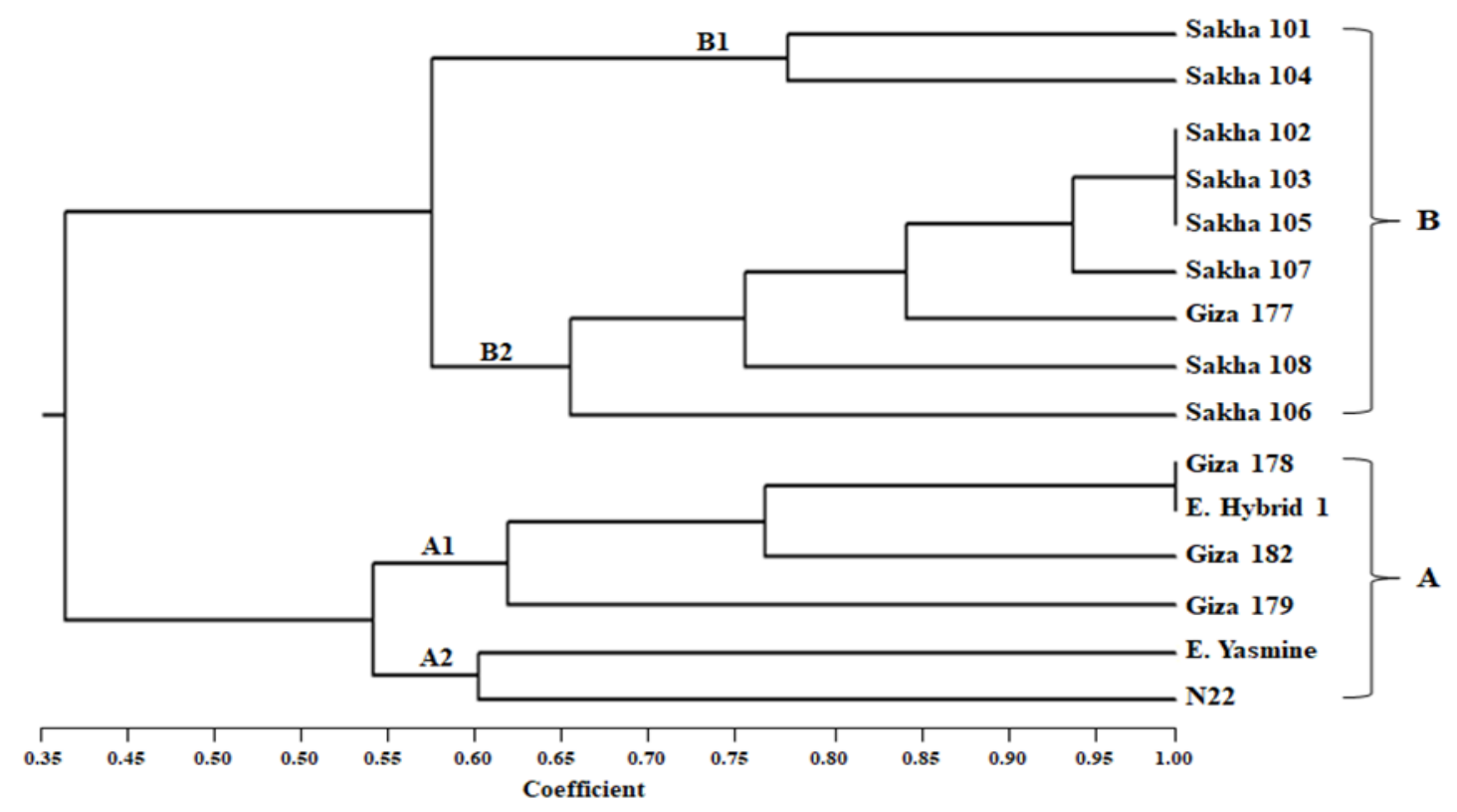

Figure (10): Dendrogram explaining the genetic relationships among tested genotypes using SSR markers employing UPGMA method.

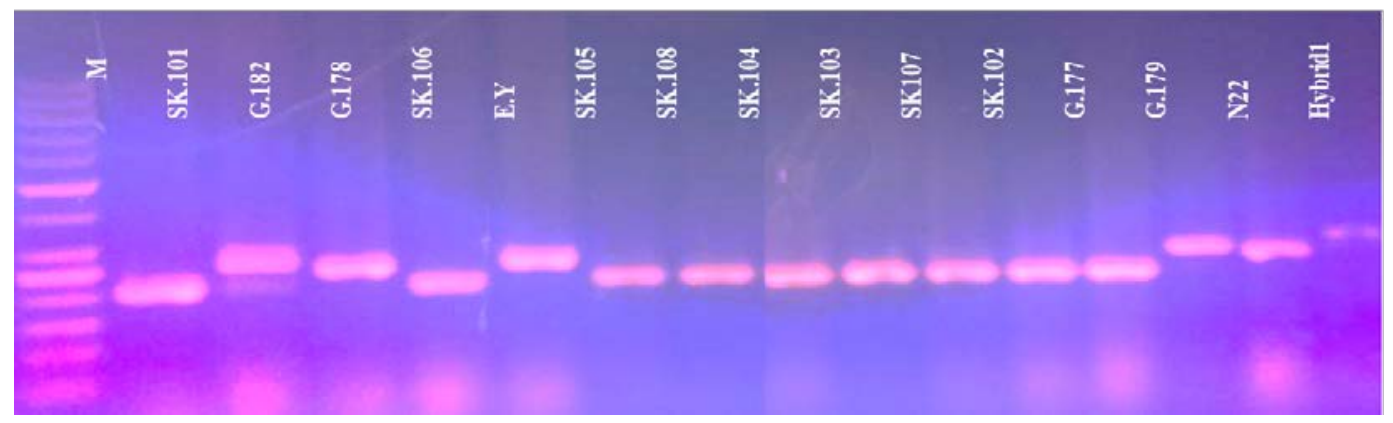

Fig. 11: The banding pattern of RM148 obtained from 15 rice genotypes (Lane 1 to 15) $M=100$ bp ladder.

\section{Conclusion}

High temperature is the most important environmental stresses reduce the performance of field crop. Generally all genotypes under heat stress produced low grain yield, the highest reduction was found in Sakha102 with value $70.36 \%$ and the lowest reduction recorded for N22 with $23.90 \%$. Among different heat indices were evaluated HRI, and MP have high correlation with grain yield/plant under normal and heat stress conditions indicting more suitability of these indices for selection of tolerant genotypes. These indices could identify Giza178, Giza179, Giza182, Egyptian Yasmin, Egyptian Hybrid1 and N22 as the best tolerant genotypes under heat condition. As well as, these genotypes were heat tolerance placed in the same cluster. The study revealed that simple sequence repeat (SSR) markers facilitated the classification of these cultivars according to their genetic background. The study also noticed that these rice cultivars had a higher genetic diversity and therefore very useful for proper identification and selection of appropriate parents for use in breeding 
programs, including gene mapping, and for application of marker assisted selection (MAS).

\section{ACKNOWLEDGMENT}

Special thanks to the Rice Biotechnology and Yield Trial Members for their support. Deep thanks to Drl Mohamed Ibrahim Ghazy Ph.D. Researcher, Rice Research and Training Center, Agricultural Research Center, for his helps to the implementation of this experiment.

\section{REFERENCES}

Abdallah, A. A. (2015). Development of High Yielding Rice Lines Tolerant to Drought and Heat Stress Conditions in Egypt. World Rural Observations. 7(1):58-64.

Abdel-Hafez, A.G., A.A. AbdAllah, I.S. EI Degwy and M.I. Ghazy (2016). Inheritance of high temperature tolerance and some related traits in rice. J., Agric., Res., Kafr El-Sheikh Univ., A- Plant Production 42(4): 623635.

Aghamolki, M.T.K., M. K. Yusop, F. C. Oad, H. Zakikhani, H. Z. Jaafar, S. Kharidah and M. H. Musa (2014). Heat stress effects on yield parameters of selected rice cultivars at reproductive growth stages. J. of Food, Agric. and Envir. Vol.12 (2): 741 - 746.

Anderson, J. A., G. A. Churchill, J. E. Autrique, S. D. Tanksley and M. E. Sorrells (1993). Optimizing parental selection for genetic linkage maps. Genome, 36(1): 181-186.

Barakat, M. N., A. A. Al-Doss, A.A. Elshafei and K. A. Moustafa (2011). Identification of new microsatellite marker linked to the grain filling rate as indicator for heat tolerance genes in $F_{2}$ wheat population. AJCS 5(2): 104-110.
Bouslama, M. and W. T. Schapaugh (1984). Stress tolerance in soybeans. Evaluation of three screening techniques for heat and drought tolerance. Crop Sci., 24: 933-937.

Bui, C.B., P. TTH, P. Bui, T.N. Tran, V.H. Nguyen and T.P. Nguyen (2014). Quantitative Trait Loci Associated with Heat Tolerance in Rice (Oryza sativa L.). P. Bre. and Biotec. 2: 14-24.

Cao, Y., Q. Zhang, Y. Chen, H. Zhao, Y. Lang, C. Yu and J. Yang (2015). Identification of differential expression genes in leaves of rice (Oryza sativa L.) in response to heat stress by CDNA-AFLP analysis. BioMed Research International, 576189.

Chen, L. and G. Wang (2011). Quantitative trait loci associated with seed set under high temperature stress at the ûowering stage in rice (Oryza sativa L.). Euphytica. 178: 331-338.

Chen, Q.; S. Yu; C. Li and T. Mou (2008). Identification of QTLs for heat tolerance at flowering stage in rice. Sci Agric Sin 41:315-321

Cheng, L. R., J. M. Wang, V. Uzokwe, L. J. Meng, Y. Wang, Y. Sun and Z. K. Li (2012). Genetic analysis of cold tolerance at seedling stage and heat tolerance at anthesis in rice (Oryza sativa L.). Journal of Integrative Agriculture, 11, 359-367.

Chu, C. G., S. Chao, T. L. Friesen, J. D. Faris, S. Zhong and S.S. XU (2010). Identification of novel tan spot resistance QTLs using an SSR-based linkage map of tetraploid wheat. Mol. Breed., 25: 327-338.

Dhanda, S. S. and Renu Munjal (2009). Cell membrane stability Combining ability and gene effects under heat stress conditions https://doi.org/10.1556/crc.37.2009.3.1 0.

Dharmendra, P. (2020). Screening for heat tolerant genotypes in bread 
wheat ( $T$. aestivum L.) using stress tolerance indices. E. J. P. B. 11(4): 1159-1164. https://doi.org/10.37992/2020.1104.187.

Doden, R., J. Kumar, G. Gouda, M. K. Gupta, M. Mukherjee, S. Y. Baksh, P.M. K. Kumar, L. Behera and S. K. Dash (2019). Assessment of Genetic Diversity of Drought Tolerant and Susceptible Rice Genotypes Using Microsatellite Markers. Rice Science, 26, No. 4.

El-Malky, M. M. H. (2007). Combining ability and genetic analysis of some quantitative characters in rice. Proc.5th Conf. Egypt. J. Plant breed. 11: 581-592.

Farrell, T. C., K. M. Fox, R. L. Williams and S. Fukai (2006). Genotypic variation for cold tolerance during reproductive development in rice: screening with cold air and cold water. Field Crops Research 98: 178-194.

Fernandez, G. C. J. (1992). Effective selection criteria for assessing plant stress tolerance. In: Kus EG (ed) Adaptation of Food Crop Temperature and Water Stress. Proceeding of 4th International Symposium, Asian Vegetable and Research and Development Center, Shantana, Taiwan, pp 257-270.

Fischer, R. A. and R. O. Maurer (1978). Crop temperature modification and yield potential in a dwarf spring wheat. Crop Sci. 16: 855-859.

Garg, H.S. and B. Chandan (2017). Drought tolerance indices for screening some of rice Genotypes. IJABR, 7 (4): 671-674.

Gavuzzi, P. F., R. Palumbo, M. Campaline, R. G. Ricciardi and G. L. Borghi (1997). Evaluations of field field and laboratory predictors and drought and heat tolerance in winter cereals. $J$. Plant Sci.m77:523-531.
Hossain, A. B. S., A. G. Sears, T. S. Cox and G. M. Paulson (1990). Desiccation tolerance and relationship to assimilate partitioning in winter wheat. Crop Sci. 30: 622-627.

IRRI, 2017 (International Rice Research Institute). Website at http://www.irri.org.

Jagadish, S., R. Muthurajan, R. Oane, T. R. Wheeler, S. Heuer, J. Bennett and P. Q. Craufurd (2010). Physiological and proteomic approaches to address heat tolerance during anthesis in rice (Oryza sativa L.). Journal of Experimental Botany 61(1):143-156.

Janni, M., M. Gullì, E. Maestri, M. Marmiroli, B. Valliyodan, H. T. Nguyen and N. Marmiroli (2020). Molecular and genetic bases of heat stress responses in crop plants and breeding for increased resilience and productivity. J. of Experi.Botany, Volume71, Issue13, 26:37803802. https://doi.org/10.1093/jxb/eraa0 34.

Khan, I. M. and O. P. Dhurve (2016). Drought response indices for identification of drought tolerant genotypes in rainfed upland rice (Oryza sativa L.). International journal of science, environment and technology. 5(1): $73-83$.

Kumar and Saravanan (2012). Genetic analysis of Cold tolerance at seedling stage and heat tolerance at anthesis in Rice (Oryza sativa L.). J Integr Agr 11(3): 359-367.

Kumar, B. S., P. J. Pragnya, K. Jitendra, B. Archana, O. N. Singh and J. N. Reddy (2014). Identification of rice germplasms associated with microsatellite (SSR) markers for heat tolerance at reproductive stage and expression of heat stress related gene. Indian Res. J. Genet. \& Biotech. 6(2): 424-427. 
Mardeh, A. S. S., A. Ahmadi, K. Poustini and V. Mohammadi (2006). Evaluation of drought resistance indices under various environmental conditions. Field Crop Res. 98: 222-229.

Mazal, T. M. (2014). Genetic studies on stem borer resistance in rice. PhD., Agric. Sc. Tanta Univ.

Murray, A. A. and W. F. Thompson (1988). Rapid isolation of high molecular weight plant DNA. Nucleic Acid Res, 8: 4321-4325.

Nagy, S., P. Poczai, I. Cernák and A. M. Gorji (2012). PICcalc: an online program to calculate polymorphic information content for molecular genetic studies. Biochem Genet, 50: 670-672.

Nakagawa, H., T. Horie and T. Matsui (2003). Effects of Climate Change on Rice Production and Adaptive Technologies. Manila, the Philippines: International Rice Research Institute: 635-658.

Ouk, M., J. Basnayake, M. Tsubo, S. Fukai, K. Fischer, M. Cooper and H. Nesbitt (2006). Use of drought respose index for identification of drought tolerant genotypes in rainfed lowland rice. Field Crops Res 99:48-58.

Pradhan, S. K., R. B. Saumya, A. Sahoo, S. Mohapatra, D. K. Nayak, A. Mahender, J. Meher, A. Anandan and E. Pandit (2016). Population Structure, Genetic Diversity and Molecular Marker-Trait Association Analysis for High Temperature Stress Tolerance in Rice.

Ramadan, E.A., G.B. Anis, M. Gawish and M. E. Mostafa (2017). Fingerprinting of some Egyptian rice genotypes using Intron-exon Splice Junctions (ISJ) markers. J Plant Mol Breed ,5(2): 38-49

Reynolds, M. P. (1994). Physiological and morphological traits associated with spring wheat yield under hot, irrigated conditions. Australian Journal of Plant Physiolology, 21: 717-730.

Rohlf, F. J. (1988). NTSYS-pc: Numerical Taxonomy and Multivariate Analysis System. Exeter Publishing

Rosielle, A. A. and J. Hamblin (1981). Theoretical aspects of selection for yield in stress and non-stress environment. Crop Sci. 21:943-946.

RRTC (2018). National Rice Research Program: Final results of 2018 growing season. Sakha, Egypt.

Sadat, S., K. A. Saeid, M. R. Bihamta, S. Torabi, S. G. H. Salekdeh and G.A.L. Ayeneh (2013). Marker Assisted Selection for Heat Tolerance in Bread Wheat. World Appl. Sci. J., 21(8): 11811189.

Saha, N. R., M. d. T. Islam and M. S. Haque (2020). Morpho-molecular screening of wheat genotypes for heat tolerance. Afr. J. Biotechnol, 19(2), pp.71-83.

Shah, F., J. Huang, K. Kul, L. Nie, T. Shah and C. Chen (2011). Impact of high temperature stress on rice plant and its traits related to tolerance. J Agric Sci 149:545-556.

Snedecor, G. W. and W. G. Cochran (1967). Statistical methods.6th ed. lowa State Univ. Press, Ames, lowa, U.S.A. SSR markers. Breeding Science. 57(4): 263-270.

Thapa, R. S., P. K. Sharma, A. Kumar and D. Pratap (2020). Screening for heat tolerant genotypes in bread wheat ( $T$. aestivum L.) using stress tolerance indices. EJPB Vol 11(4):1159-1164. https://doi.org/10.37992/2020.1104.187

Wahid, A., S. Gelani, M. Ashraf and M. R. Foolad (2007). Heat tolerance in plants: An overview, Environmental and Experimental Botany.6: 199- 223.

Xiao, Y., Y. Pan, L. Luo, G. Zhang, H. Deng, L. Dai, $X$. Liu and $W$. Tang (2011). Quantitative trait loci associated with seed set under high 
temperature stress at the flowering stage in rice. Euphytica. 178: 331-338.

Xu, J., A. Henry and N. Sreenivasulu (2020). Rice yield formation under high day and night temperatures $A$ prerequisite to ensure future food security. Plant Cell Environ. 43:15951608.

wileyonlinelibrary.com/journal/pce.

Xue, D.W., H. Jiang, J. Hu, X.Q. Zhang, L. B. Guo, D. L. Zeng, G. J. Dong, G. C. Sun and Q. Qian (2012). Characterization of physiological response and identification of associated genes under heat stress in rice seedlings. Plant Physiol Biochem 61:46-53

Yin, X., M. J. Kroff and J. Goudriaaa (1996). Differential effects of day and night temperature on development to flowering in rice. Annals of Botany 77: 203-213.

Yoshida, S., T. Satake and D. S. Mackill (1981). High temperature stress in rice, IRRI Research Paper Series, Vol. 67.

Zhang, G., L. Chen, G. Xiao, Y. Xiao, X. Chen and S. Zhang (2008). Bulked segregant analysis to detect QTL related to heat tolerance in rice (Oryza sativa L.) using SSR markers. Agricultural sciences in China. 8(4): 482-487.

Zhao, L., J. Lei, Y. Huang, S. Zhu, H. Chen, R. Huang, Z. Peng, Q. Tu, X. Shen and S. Yan (2016). Mapping quantitative trait loci for heat tolerance at anthesis in rice using chromosomal segment substitution lines. Breed Sci 66(3): 358-366. 
التقييم الحقلى والوراثى للتحمل للاجهاد الحرارى لبعض أصناف الأرز باستخدام دلائل SSR الإجهاد ومعلمات

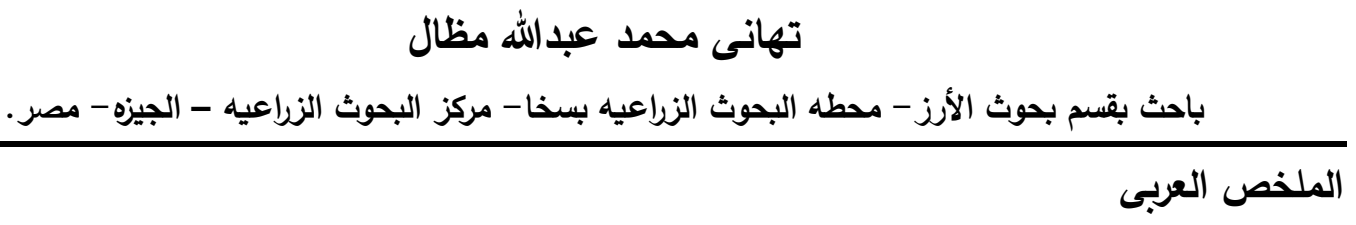

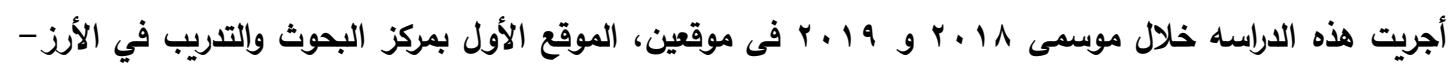

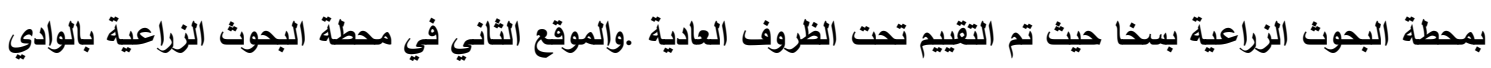

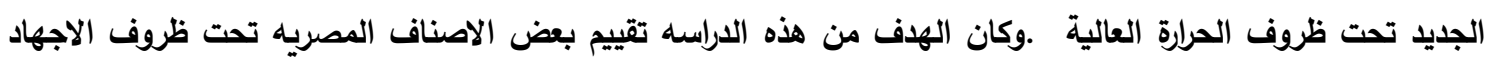

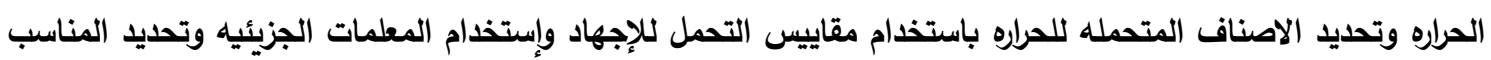
من هذه المعلمات واستخدامها بعد ذلك فى التربيه للتحمل للاجهاد الحرارى.حيث تم تقييم 10 تركيب وراثى من الأرز

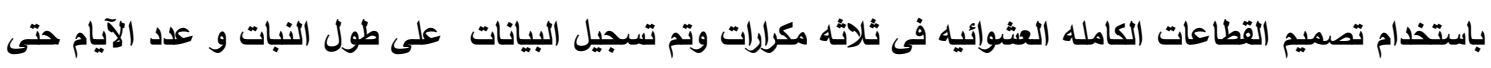

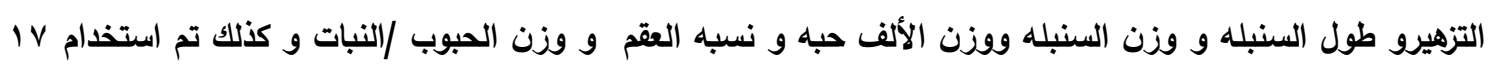

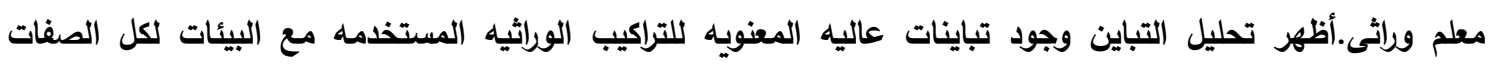

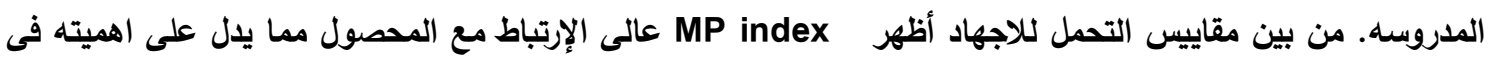
تحديد التراكيب الوراثيه المتحمله للحراره. تم الحصول على أفضل متوسط قيم فى المحصول تحت الظروف العاديه وإلحصول على أفضل تركيب وراثى تحت التحاكت

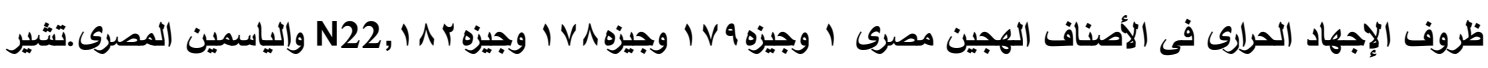
النتائج الى أهميه هذه التراكيب الوراثيه لنقل صفات تحمل الاجهاد الحرارى فى الأرذ فى برامج التربئ التربيه.أظهرتحليل المعلمات

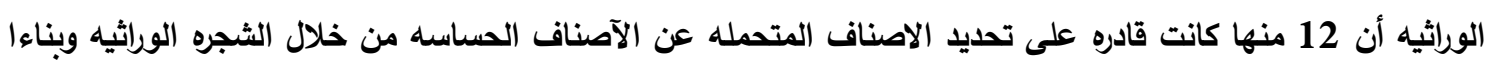

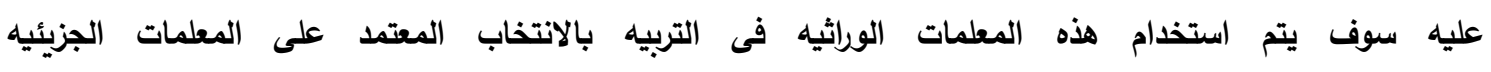
(RM6100,RM160,RM310,RM3471,RM225,RM592,RM148,RM153,RM5687,RM471,RM43

RMr०^4, 0,RM440)

أسماء السادة المحكمين

أ.د// صابر السيد صديق مركز البحوث الزراعية المبية أ.د/ حسان عبد الجيد دوام كلية الزراعة - جامعة المنوفية البرية 